\title{
Microbiology, proximate and functional properties of flour produced from three different varieties of cassava (Manihot esculenta Crantz)
}

\section{Oluwole Olakunle Oladele* and Oluwafunmilola Olajumoke Makinde}

Department of Biology, Federal University of Technology, Akure, Ondo State, Nigeria. *Email: prophetoladele2014@gmail.com.

\begin{abstract}
Microbiology, proximate and functional properties of flour produced from three different varieties (TMS 1371, TME 419 and TMS 92/0326) of cassava (Manihot esculenta Crantz) were investigated in this research work. The flour was subjected to microbial, proximate and functional analyses. Microbial analysis was carried out using pour plate technique and the agar used were nutrient agar for bacteria count and isolation while malt extract agar was used for fungi count and isolation. Proximate and functional analyses were done using standard methods. Results obtained showed that bacterial count $(\mathrm{cfu} / \mathrm{mL})$ of each flour ranging from $5.33 \times 10^{1}$ (TME 419) to $7.67 \times 10^{1}$ (TMS 92/0326) was higher than the fungi count (sfu/ml) which ranged from $0.66 \times 10^{1}$ (TMS 92/0326) to $4.0 \times 10^{1}$ (TMS 1371). The bacteria identified were Lactobacillus sp. which were present in all the flours and Bacillus sp. which was only present in flour obtained from TME 419 and TMS 92/0326. The only fungus present in all the flour was Rhizopus sp. The proximate values of flour from TMS 1371 showed that the moisture content (11.44\%), ash (1.11\%), fat (6.93\%) and crude protein $(7.46 \%)$ were higher when compared with flour from TME 419 and TMS 92/036. However, carbohydrate $(69.05 \%)$ and crude fibre (7.41\%) were higher in TME 419 and TMS 92/036. Also, TMS 92/0326 flour was higher in dispensability (59.94 mL), swelling capacity $(5.18 \%)$ and solubility index (9.26) while bulk density $(10 / 25.20 \mathrm{~g} / \mathrm{mL})$ was higher in TMS 1371 . Despite variations in values, results from this study showed that the proximate and functional properties of flour obtained from each variety still conformed to the minimum requirements of high quality cassava flour.
\end{abstract}

Keywords: Flour; Microbiology; Proximate; Functional; Cassava varieties.

\section{Introduction}

For the past decades, increasing population, urbanization and change in
Received

April 24, 2018

Accepted

August 26, 2018

Released

August 31, 2018

Full Text Article

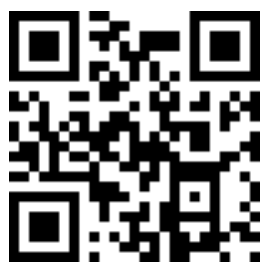

ORCID
0000-0001-9023-2646
Oluwoler Olakunle
Oladele

(ㄱ) 0000-0003-1188-3139

Oluwafunmilola

Olajumoke Makinde food habit has led to an increased demand for wheat-based convenient food in many developing countries (Eriksson et al., 2013). This in turn has 
also led to an interest in cassava flour as a partial substitute for wheat flour. But then, cassava has a lot of varieties and each variety has different compositions which have brought about difficulty in choosing the best variety to be used in the production of high quality cassava flour considering the fact that the variety of cassava used in producing the flour also determines the flour's functional attributes. There are different varieties of cassava in Nigeria. They can be distinguished by their morphological characteristics such as leaf size, colour and shape, branching habit, colour of stem and petiole, tuber shape and colour, time to maturity and yield (IITA, 1999). Examples of the improved varieties bred in IITA are TMS/4(2)1425, TMS 82/00058, TMS 91/02324, TMS 92/0057, TMS 92/0067, TMS 92/0325, TMS 92/0326, TMS 94/0026, TMS 94/0039, TMS94/0561, TMS 95/0166, TMS 95/0289, TMS 95/0379, TMS 96/0523, TMS 96/0603, TMS 96/1632, TMS 96/1642, TMS 97/0162, TMS 97/0211, TMS 97/2205, TMS 98/2101, TMS 98/2226, TMS 99/2123, TMS 99/3073, etc. (IITA, 1999).

Fresh cassava cannot be stored for long because they rot within 3-4 days of harvest. They are bulky with about $70 \%$ moisture content which makes transportation of the roots to urban market difficult and expensive. As cassava contains toxic compounds, it requires special processing procedures that will eliminate or reduce the levels of cyanogenic glucosides, making the product safe for human consumption. Consequently, cassava products are safe if processed properly (Dziedzoave et al., 2006) and can be processed into fufu, garri, starch, flour, etc. The production process of high quality cassava flour (HQCF) was initially developed at the International Institute for Tropical Agriculture (IITA) in Nigeria as an alternative to imported wheat flour for food and non-food industry and the technology is now used in some cassavagrowing nations (Falade and Akingbala,
2008). Hence, this research was conducted to compare the microbiology, proximate and functional attributes of cassava flour produced from three different varieties of cassava to ascertain its suitability as HQCF.

\section{Materials and methods}

\section{Source and collection of cassava flour \\ Cassava flours (each flour} produced from each variety - TMS 1371, TME 419 and TMS 92/0326) were obtained from International Institute of Tropical Agriculture, Ibadan, Nigeria. The samples were respectively labeled according to the name of each variety and brought to the Department of Biology Laboratory, Federal University of Technology, Akure, Nigeria for microbial, proximate and functional analyses.

\section{Preparation of culture media}

The culture media used for detecting the presence, count and isolation of any bacteria present in the flour was nutrient agar while malt extract agar (MEA) was used for detecting the presence, count and isolation of any fungi present.

\section{Counting and isolation of microorganisms}

Pour-plate technique was used for counting and isolation of bacteria present in each of the flours. One gram of flour was serially diluted with sterile distilled water to primary dilutions $\left(\times 10^{1}\right)$. One milliliter $\left(\times 10^{1}\right)$ of dilution flour was then pipetted into a sterilized Petri-dish aseptically. This was followed by the pouring of already prepared sterilized molten Nutrient agar medium. The Petri dish was later swirled gently to allow the contents to mix together, then allowed to solidify and incubated at $28 \pm$ $2{ }^{\circ} \mathrm{C}$ for $24 \mathrm{~h}$. After $24 \mathrm{~h}$, bacteria count was carried out with a colony counter (Gallenkamp model). Sub culturing of any observable isolate was done several times until a pure culture was obtained. 
The same procedure was repeated for fungi count and isolation except that the agar used was malt extract and the counting was done after $72 \mathrm{~h}$.

\section{isolates \\ Identification of microbial \\ The bacteria were identified} based on their colonial morphology, cellular morphology and their biochemical characteristics. Each isolate was identified using the text of Buchanan and Gibbons (1974). Basic classification and identification tests on the fungi encountered were carried out using the criteria outlined by Frazier and Westhoff (1998). A drop of lactophenol solution was put on a slide. The test fungal isolate was placed on the slide and stained with the lactophenol and was then covered with a cover slip. Excess liquid was drained off with a filter paper and examined under a binocular microscope at $40 \times$ objective magnification.

\section{flour}

\section{Proximate analysis of cassava}

The proximate analysis of flour was carried out using the standard procedure of Association of Analytical Chemist (AOAC, 2000). The proximate analysis carried out included determination of moisture content, crude protein, crude fibre, crude fat, ash content and carbohydrates.

\section{properties}

\section{Determination of functional}

The functional properties of flour were carried out using the standard procedure of Association of Analytical Chemist (AOAC, 2006). The functional properties carried out included determination of solubility index, swelling capacity, bulk density and dispensability.

\section{Determination of hydrogen cyanide (HCN) content}

The HCN content of flour was estimated using the standard procedure of Association of Analytical Chemist (AOAC, 2000).

\section{flour}

\section{Determination of $\mathrm{pH}$ of cassava}

The $\mathrm{pH}$ value of cassava flour was obtained using a $\mathrm{pH}$ probe meter (ModelHI96107). One gram of the flour was dissolved in $10 \mathrm{~mL}$ of distilled water after which the $\mathrm{pH}$ loop was dipped inside the beaker containing the dissolved flour and the reading was taken and recorded.

\section{Statistical analysis}

Data was analyzed using one-way ANOVA. Means were separated by Tukey Posthoc Test, with the significant difference level of $\mathrm{p}=0.05$ (software SPSS version 11.5).

\section{Results}

\section{cassava flour \\ Microbial counts of each}

Cassava flour produced from TMS 1371 had a bacteria count of $5.67 \times 10^{1}$ $\mathrm{cfu} / \mathrm{mL}$ and a fungi count of $4.00 \times 10^{1}$ $\mathrm{sfu} / \mathrm{mL}$. Also, the respective bacteria and fungi counts of flour produced from TME 419 were $5.33 \times 10^{1} \mathrm{cfu} / \mathrm{mL}$ and $1.00 \times 10^{1} \mathrm{sfu} / \mathrm{mL}$, respectively. For flour obtained from TMS 92/0326, the bacteria and fungi counts were $7.67 \times$ $10^{1} \mathrm{cfu} / \mathrm{mL}$ and $0.66 \times 10^{1} \mathrm{sfu} / \mathrm{mL}$, respectively (Table 1 ).

\section{Morphological \\ biochemical characteristics of \\ bacteria found in cassava flour}

The morphological and biochemical characteristics of bacteria isolates found in cassava flour are 
presented in Table 2. Lactobacillus sp. was found in cassava flour obtained from each variety while Bacillus sp. was found only in flour obtained from TMS 419 and TMS 92/0326 variety (Table 2).

\section{Morphological characteristics of fungi found in cassava flour}

Rhizopus sp. was the only fungus found in all the flours. The isolate appeared whitish, fluffy and cottony in texture on malt extract agar. Microscopically, the sporangiophores were erect and occurred in groups opposite the rhizoids. The sporangia were oval and angular in shape.

\section{Proximate compositions of cassava flour obtained from three different varieties}

Results of the proximate compositions of cassava flour obtained from three different varieties are shown in Table 3. The results indicated that there was no significant difference $(\mathrm{p}<0.05)$ in the moisture contents of cassava flour produced from TMS 1371 and TME 419 whose respective values were $11.44 \pm 0.07$ and $10.00 \pm 0.14 \%$. However, the moisture content of TMS $92 / 0326 \quad(9.80 \pm 0.41 \%) \quad$ was significantly different from the moisture content of flours obtained from TMS 1371 and TME 419 (Table 3). Also, the ash contents of flour obtained from TME 419 having a value of $0.82 \pm 0.04 \%$ and TMS 92/0326 with a value of $0.70 \pm 0.01$ were not significantly different from each other but significantly different from the ash content of flour produced from TMS 1371 with a value of $1.11 \pm 0.05 \%$. Results of the crude fibre equally showed that the crude fibre contents of flour obtained from TMS 1371 and TME 419 having respective values of $5.96 \pm 0.09$ and $5.91 \pm 0.11 \%$ were not significantly different from the crude fibre of flour obtained from TMS 92/0326 with a value of $7.41 \pm 0.15 \%$ (Table 3 ).

Table 1. Microbial counts of each cassava flour.

\begin{tabular}{lcc}
\hline Flour/variety & $\begin{array}{c}\text { Bacteria count } \\
\left(\times \mathbf{1 0}^{\mathbf{1}} \mathbf{c f u} / \mathbf{m L}\right)\end{array}$ & $\begin{array}{c}\text { Fungi count } \\
\left(\times \mathbf{1 0}^{\mathbf{1}} \mathbf{s f u} / \mathbf{m L}\right)\end{array}$ \\
\hline TMS 1371 & $5.67 \pm 1.30^{\mathrm{a}}$ & $4.00 \pm 0.67^{\mathrm{a}}$ \\
TME 419 & $5.33 \pm 1.76^{\mathrm{a}}$ & $1.00 \pm 0.54^{\mathrm{ab}}$ \\
TMS 92/0326 & $7.67 \pm 2.40^{\mathrm{a}}$ & $0.66 \pm 0.44^{\mathrm{a}}$ \\
\hline
\end{tabular}

Mean \pm SE of triplicate $(n=3)$ followed by the same letter in a column are not significantly different ( $p>0.05$ ) by Tukey Posthoc Test.

Cfu-Colony forming unit;

Sfu-spore forming unit

Meanwhile, there were no significant differences in the fat contents of flour obtained from TMS 1371, TME 419 and TMS 92/0326 variety. Their respective fat contents were $6.93 \pm 0.09$, 7. $03 \pm 0.19$ and $6.85 \pm 0.09 \%$. Similarly, there were no significant difference as in the crude protein contents of flour obtained from TMS 1371, TME 419 and TMS 92/0326 having respective values of $7.46 \pm 0.61,6.38 \pm 0.28$ and $6.94 \pm 0.54$ (Table 3).
Results of the functional properties of cassava flour obtained from three different varieties are shown in Table 4. The results indicated that there was significant difference $(p<0.05)$ in the bulk density of cassava flour produced from TMS 1371, TME 419 and TMS 92/0326 whose respective values were $10 / 25.20 \pm 0.11,10 / 21.37 \pm 0.19$ and 10/23.23 \pm 0.07 (Table 4). Also, dispensability of flour obtained from TMS 1371 having a value of $41.12 \pm 0.22$ 
was significantly different from that obtained from TME 419 and TMS $92 / 0326$ whose respective values were $59.93 \pm 0.30$ and $59.94 \pm 0.08$. However the respective values were not significantly different from each other (Table 4). Results of the swelling capacity of flour obtained from TMS 1371 and TMS 92/0326 with respective values of $5.13 \pm 0.05$ and $5.18 \pm 0.36$ were significantly different from that of flour obtained from TME 419 with a value of $4.17 \pm 0.60 \%$ (Table 4 ). Meanwhile, the solubility index of flour obtained from TMS 1371 and TME 419 with respective values of $8.16 \pm 0.09$ and $8.26 \pm 0.07$ were not significantly different from each other but were significantly different from solubility index of flour obtained from TMS 92/0326 with a value of $9.26 \pm$ 0.16 (Table 4).

Table 2. Morphological and biochemical characteristics of bacterial isolates found in each cassava flour.

\begin{tabular}{|c|c|c|c|c|c|}
\hline \multirow{2}{*}{ Parameters } & \multicolumn{5}{|c|}{ Flour/variety } \\
\hline & TMS 1371 & \multicolumn{2}{|c|}{ TME 419} & \multicolumn{2}{|c|}{ TMS 92/0326 } \\
\hline Colour & Creamy & Creamy & White & Creamy & White \\
\hline Shape & Rod & Rod & Rod & Rod & Rod \\
\hline Edge & Entire & Entire & Entire & Entire & Entire \\
\hline Elevation & Flat & Flat & Flat & Flat & Flat \\
\hline Texture & Soft & Soft & Soft & Soft & Soft \\
\hline Gram's reaction & + & + & + & + & + \\
\hline Catalase & + & + & + & + & + \\
\hline Coagulase & - & - & - & - & - \\
\hline Starch hydrolysis & - & - & + & - & + \\
\hline Glucose & + & + & + & + & + \\
\hline Lactose & + & + & + & + & + \\
\hline Maltose & + & + & + & + & + \\
\hline Likely organism & $\begin{array}{l}\text { Lactobacillus } \\
\text { sp. }\end{array}$ & $\begin{array}{l}\text { Lactobacillus } \\
\text { sp. }\end{array}$ & $\begin{array}{l}\text { Bacillus } \\
\text { sp. }\end{array}$ & $\begin{array}{l}\text { Lactobacillus } \\
\text { sp. }\end{array}$ & $\begin{array}{c}\text { Bacillus } \\
\text { sp. }\end{array}$ \\
\hline
\end{tabular}

$+=$ Positive; - = Negative

Table 3. Proximate composition of each cassava flour.

\begin{tabular}{lcccccc}
\hline & \multicolumn{5}{c}{ Proximate parameters } \\
\cline { 2 - 7 } Flour/variety & Moisture & Ash & Fat & Crude fibre & $\begin{array}{c}\text { Crude } \\
\text { protein }\end{array}$ & CHO \\
\hline TMS 1371 & $11.44 \pm 0.07^{\mathrm{b}}$ & $1.11 \pm 0.05^{\mathrm{b}}$ & $6.93 \pm 0.09^{\mathrm{a}}$ & $5.96 \pm 0.09^{\mathrm{a}}$ & $7.46 \pm 0.61^{\mathrm{a}}$ & $67.09 \pm 0.64^{\mathrm{a}}$ \\
TME 419 & $10.00 \pm 0.14^{\mathrm{a}}$ & $0.82 \pm 0.04^{\mathrm{a}}$ & $7.03 \pm 0.19^{\mathrm{a}}$ & $5.91 \pm 0.11^{\mathrm{a}}$ & $6.38 \pm 0.28^{\mathrm{a}}$ & $69.05 \pm 0.53^{\mathrm{b}}$ \\
TMS 92/0326 & $9.80 \pm 0.41^{\mathrm{a}}$ & $0.70 \pm 0.01^{\mathrm{a}}$ & $6.85 \pm 0.09^{\mathrm{a}}$ & $7.41 \pm 0.15^{\mathrm{b}}$ & $6.94 \pm 0.54^{\mathrm{a}}$ & $68.29 \pm 0.61^{\mathrm{ab}}$ \\
\hline
\end{tabular}

Mean \pm SE of triplicate $(n=3)$ followed by the same lower case letter in a column are not significantly different ( $p>0.05$ ) by Tukey posthoc test.

CHO- carbohydrate. 
Table 4. Functional properties of each cassava flour.

\begin{tabular}{lcccc}
\hline Flour/variety & $\begin{array}{c}\text { Bulk density } \\
(\mathbf{g} / \mathbf{m L})\end{array}$ & $\begin{array}{c}\text { Dispensability } \\
(\mathbf{m L})\end{array}$ & $\begin{array}{c}\text { Swelling capacity } \\
(\%)\end{array}$ & $\begin{array}{c}\text { Solubility } \\
\text { index }\end{array}$ \\
\hline TMS 1371 & $10 / 25.20 \pm 0.11^{\mathrm{a}}$ & $41.12 \pm 0.22^{\mathrm{a}}$ & $5.13 \pm 0.05^{\mathrm{b}}$ & $8.16 \pm 0.09^{\mathrm{a}}$ \\
TME 419 & $10 / 21.37 \pm 0.19^{\mathrm{b}}$ & $59.93 \pm 0.30^{\mathrm{b}}$ & $4.17 \pm 0.60^{\mathrm{a}}$ & $8.26 \pm 0.07^{\mathrm{a}}$ \\
TMS 92/0326 & $10 / 23.23 \pm 0.07^{\mathrm{c}}$ & $59.94 \pm 0.08^{\mathrm{b}}$ & $5.18 \pm 0.36^{\mathrm{b}}$ & $9.26 \pm 0.16^{\mathrm{b}}$ \\
\hline
\end{tabular}

Mean \pm SE of triplicate $(n=3)$ followed by the same lower case letter in a column are not significantly different $(\mathrm{p}>0.05)$ by Tukey posthoc test.

\section{Hydrogen cyanide contents of cassava flour obtained from three different varieties of cassava}

The results of hydrogen cyanide of cassava flour obtained from three different varieties are shown in Table 5. The results indicated that there was significant difference $(p<0.05)$ in the cyanide contents of cassava flour produced from all the varieties. HCN of flour obtained from TMS 1371 and TME 419 were $0.047 \pm 0.03$ and $0.553 \pm 0.01$, respectively, whereas HCN of flour from TMS 92/0326 was $0.477 \pm 0.00$ (Table 5).

Table 5. Hydrogen cyanide content (HCN) of each cassava flour.

\begin{tabular}{lc}
\hline Variety & HCN (mg/kg) \\
\hline TMS 1371 & $0.047 \pm 0.03^{\mathrm{a}}$ \\
TME 419 & $0.553 \pm 0.01^{\mathrm{c}}$ \\
TMS 92/0326 & $0.477 \pm 0.00^{\mathrm{b}}$ \\
\hline
\end{tabular}

Mean \pm SE of triplicate $(n=3)$ followed by the same letter in a column are not significantly different $(\mathrm{p}>0.05)$ by Tukey posthoc test.

\section{pH of cassava flour}

The $\mathrm{pH}$ value of each cassava flour obtained from three varieties is shown in Table 6. The results indicated that there was no much difference in the three varieties namely TMS 1371, TMS TME 419 and TMS 92/0326 with the value $6.74,6.72$ and 6.59 , respectively.
Table 6. $\mathrm{pH}$ value of each cassava flour.

\begin{tabular}{ll}
\hline \multicolumn{1}{c}{ Variety } & pH \\
\hline TMS 1371 & 6.74 \\
TME 419 & 6.72 \\
TMS 92/0326 & 6.59 \\
\hline
\end{tabular}

\section{Discussion}

The emergence of Rhizopus sp, Bacillus sp. and Lactobacillus sp. in cassava flour suggests possible contamination by spores in the air. The light spores of this organism might be present in surrounding air of the production unit where the samples were processed. This observation was supported by the report of Arotupin et al. (2003) that environmental contamination was responsible for the presence of Aspergillus niger, Aspergillus flavus and Rhizopus sp. since their spores are common contaminants. From the microbial count, the study revealed that the bacteria load was higher than that of fungi which suggests that the $\mathrm{pH}$ of the flour which was within the range of 6.59 -6.74 supports the growth of bacteria than fungi. Bacteria prefer $\mathrm{pH}$ between 6.5 and 7.5 which is buttressed by the work of Ann (1994). However, that of fungi was reduced and this could be due to the fact that fungi are acid tolerant and increase in population of fungi is due to acidic condition (Adegunloye, 2012).

The proximate analysis revealed differences in moisture contents of the flour which could be attributed to 
varietal differences particularly age of each variety at harvest (Eriksson, 2013). However, \% moisture content of each flour still conformed to the standard moisture content of high quality cassava flour which could probably be a factor for low microbial count of the flour. Also, the crude fiber and ash contents were close to the standard requirement for high quality cassava flour. According to Abass et al. (1998) and Grafham et al. (2000), the standard for \% moisture, ash, crude fiber contents is $\leq 10,3$ and $2 \%$, respectively. The values obtained for the crude protein and fat were also similar to the value obtained by Tharise et al. (2014).

The bulk density, swelling capacity, dispensability and solubility index of each flour were also similar to those obtained by Eriksson et al. (2013) and also conformed to the standard requirement of high quality cassava flour. This could be attributed to the fact that the varieties of cassava used in producing the cassava flour were of good quality. This can be buttressed with the fact that the variety of cassava used in production determines the functional properties of the end product (Dziedzoave et al., 2006). The study also revealed that the value of $\mathrm{HCN}$ were acceptable even though there was no fermentation. This could possibly be because there was effective processing of the cassava flour. Effective processing reduces the cyanide of cassava (Dziedzoave et al., 2006).

\section{Conclusion}

The study has shown that the different varieties (TMS 1371, TME 419 and TMS 92/0326) of cassava used in the production of cassava flour affect the proximate, functional and cyanide contents of the flour significantly. However, the three varieties produced flour that satisfies the standard requirements for high quality cassava flour in terms of proximate, functional and cyanide values.

\section{Conflict of interest}

The authors declare that they have no conflict of interest in the publication.

\section{References}

Abass, A. B.; Onabolu, A. O.; Bokanga, M. Impact of high quality cassava flour technology in Nigeria. In: Akoroda, M. 0.; Ngeve, J. M. (Comp.). Root crops in the $21^{\text {st }}$ century. Proceedings of the $7^{\text {th }}$ Triennial Symposium of the International Society for Tropical Root Crops. Africa Branch (ISTRC$\mathrm{AB})$. Centre International des Conferences, Cotonou, Benin, p. 11-17, 1998.

Adegunloye, D. V. Assessment on fermentation and bioconversion of some oil palm (Elaeis guineensis L.) wastes. FUTA Journal of Research in Sciences, v. 8, p. 4851, 2012.

Ann, F. Food Microbiology. Oxford: Heinemann Educational Publishers, 1994.

AOAC - Association of Official Analytical Chemists. Official Methods of Analysis. 17. ed. Washington, D.C.: Association of Official Analytical Chemists, 2000.

AOAC - Association of Official Analytical Chemists. Official Methods of Analysis. 18. ed. Washington, D.C.: Association of Official Analytical Chemists, 2006.

Arotupin, D. J.; Akinyosoye, F. A.; Oladele, O. O. Microbial Quality of Selected commercially packaged chocolaty beverages in Akure, Nigeria. Journal of Nigerian Society for Experimental Biology, v. 3, no. 2, p. 35-41, 2003.

Buchanan, R. E.; Gibbons, N. E. Bergey's Manual of Determinative Bacteriology. 8. ed. 1974.

Dziedzoave, N. T.; Abass, A. B.; Amoa-Awua W. K. A.; Sablah, M. Quality management manual for production of high quality cassava flour. International Institute of Tropical Agriculture Report, 2006.

Eriksson, E.; Koch, K; Tortoe, P; Akonor, T; Baidoo, E. Physicochemical, functional and pasting characteristics of three varieties of cassava in wheat composite flours. British Journal of Applied Science Technology, v. 4, no. 11, p. 1609-1621, 2013.

Falade, K.; Akingbala, J. Improved nutrition and national development through the 
utilization of cassava in baked foods. In: Robertson, G. L.; Lupien, J. R. (Eds.). Food science and technology to improve nutrition and promote national development. International Union of Food Science and Technology, 2008.

Frazier, W. C.; Westhoff, D. C. Food Microbiology. 4. ed. Singapore: Tata McGrawHill Publication1998.

Graffham, A. J.; Dziedzoave, N. T.; Ayenor, G. S. Final technical report of the CPHP project entitled "Expanding markets for cassava starches and flours in Ghana". Report of the Natural Resources Institute (RS504), 2000.
IITA. IITA Annual report for 1999. Evaluation of new improved breed lines without insecticide sprays. Project 11. 1999.

Tharise, N.; Julianti, E.; Nurminah, M. Evaluation of physico-chemical and functional properties of composite flour from cassava, rice, potato, soybean and Xanthan gum as alternative of wheat flour. International Food Research Journal, v. 21, no. 4, p. 1641-1649, 2014. 